\section{A.H. Verhoef}

Prof. A.H. Verhoef, School

of Philosophy, Humanities,

North-West University.

(orcid.org/0000-0002-9627-1969)

anne.verhoef@nwu.ac.za

\section{J. du Toit}

\section{Dr J. du Toit, School of}

Philosophy, Humanities,

North-West University.

(orcid.org/0000-0002-5297-8241)

jean.dutoit@nwu.ac.za

\section{P. du Preez}

Prof. P. du Preez, School

of Professional Studies

in Education, Education,

North-West University.

(orcid.org/0000-0002-9100-6461)

petro.dupreez@nwu.ac.za

DOI: http://dx.doi.

org/10.18820/23099089/actat. v40i2.19

ISSN: 1015-8758 (Print)

ISSN: 2309-9089 (Online)

Acta Theologica 2020

40(2):150-164

Date received:

4 August 2020

Date accepted:

20 October 2020

Date published:

18 December 2020

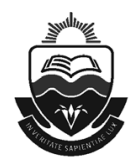

Published by the UFS

http://journals.ufs.ac.za/index.php/at

(C) Creative Commons

With Attribution (CC-BY)

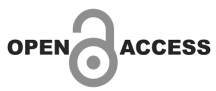

\section{BEING-IN-THE-}

COVID-19-WORLD:

EXISTENCE,

TECHNOLOGY AND

EMBODIMENT

\section{ABSTRACT}

The multifaceted nature of COVID-19 permeates all dimensions of human life. In this article, we argue that the COVID-19 crisis might teach us something about dealing with ruptures of this kind and scope in the future. The pandemic challenges our Being-in-the-world and it has the potential to help us realise the authentic possibilities of our own being - a freedom we have in our being-towardsdeath. We contemplate the extent to which this pandemic has caused existential angst and resultant reflection. To this end, we analyse, with reference to the work of Martin Heidegger, the existential and technological challenges that accompany the pandemic. We postulate that the pandemic has forced us to think about our existence more authentically, away from the "fallenness" of the ontological structure of Dasein in its everydayness. It proffers the opportunity to reconsider what authentic existence, technology, and embodiment entail amidst COVID-19 and for the future.

\section{INTRODUCTION}

The COVID-19 pandemic is a multifaceted crisis that permeates all dimensions of human life and challenges the very nature of our existence (or, in Heideggerian terms, our being-in-the-world). The pandemic brings with it various degrees of existential angst. At the time of writing this article, there are over 44 million diagnosed COVID-19 cases globally, which have resulted in nearly 
1.17 million deaths. Du Preez and Le Grange (2020) describe that South Africa is one of the countries that has introduced the strictest lockdown measures that involved taking drastic steps to contain the virus and to save lives. Du Preez and Le Grange (2020:3) further postulate that

[t]he lockdown measures will impact negatively on the global economy and we await what might be the deepest global recession since the Great Depression of the late 1920s and early 1930s.

However, while presenting a rupture in our existence, this pandemic has also served to affirm life in various ways such as highlighting various social problems, for example:

\begin{abstract}
health professionals working tirelessly to save lives, peoples' solidarity and generosity across the globe, a rejuvenating planet, as we see turtles return to desolate beaches in India and Brazil, fish returning to rivers where they have not been seen in years, blue skies in Delhi as air pollution levels decline, and so forth. Moreover, we have come to value those often under-valued by society such as health care professionals, cashiers, police persons, teachers, etc. But, we have also witnessed deaths, inequality laid bare, poverty, unemployment, the negative psychological effects of forced isolation, and so forth (Du Preez \& Le Grange 2020:3).
\end{abstract}

The COVID-19 pandemic has, therefore, been a multifaceted and farreaching event in our contemporary times. However, the contemporaneous uncertainty has also had a direct bearing on individuals' mental health. For example, according to the World Health Organization (2020), people's mental health has been negatively affected by COVID-19 through "fear, worry, and stress", but also through restrictions on their movements. Psychological succour (often in the form of coping tips) were continuously provided during the highest level of lockdown. Many individuals also sought religious and philosophical interventions as they struggled to navigate themselves spiritually, psychologically, emotionally, physically, economically, and even existentially (examples of this include the efforts of groups such as the South African Society of Psychiatrists). In light of this, huge swathes of the population have consulted vast amounts of online resources, in order to arrive at strategies that might assist in alleviating aspects of this situation (Greenberg 2020).

As the lockdown progressed, technology, especially social media and communication platforms, began to play ever more pertinent and prominent roles in our daily existence. The forced ubiquity of our engagement with technology suggests that we must ask once more whether technology should be assessed in a predominantly positive manner, as is often suggested by technophiles globally. Instead, we ask, might the lockdown reveal some 
deleterious effects as resultant from our technology use? We argue that such a closer reflection on our being through technology necessitates that we pause and (re)consider our Being-in-the-COVID-19-world.

In this article, we focus on the existential challenges and angst that the COVID-19 pandemic has caused (especially in relation to our expanded use of digital technologies), while being ever so aware of the challenges (psychologically, economically, and so on) that are profoundly interrelated and persistently increased during this period. We further demarcate our scope and analysis of the existential angst caused by COVID-19, by relying on the work of Martin Heidegger. First, because of his brilliant and seminal exposition of Dasein and, secondly, because - in his later work - he offered a unique perspective on technology. Heidegger introduced a concept that has proved to be fundamental to the development of both existential phenomenology and existentialism in the 20th century, that of Dasein, and that he has a welldeveloped philosophy of technology that is particularly suitable for the current analysis, because it approaches technology from an existential angle. We will consider two major works of Heidegger in our analysis of COVID-19, namely Being and time - originally published in 1926 - and The question concerning technology (1977). These will be brought into conversation with the authors' own experiences of the lockdown in South Africa.

\section{BEING-TOWARDS-DEATH AND BEING-IN-THE-WORLD}

We cannot be locked down and unable to escape from our sense of being; our awareness of our existence. The life-threatening COVID-19 pandemic became an overwhelming reality, and we were ever more confronted by the fact that we exist and that this existence might suddenly come to an end. This is an awareness of our Dasein as a Being-towards-death. Lockdown, as a period of isolation and COVID-19-induced anxiety, forced us to think again about our being. We were forced to confront the fact of our existence, i.e. as finite and limited beings, to such an extent that we (at least, the authors of this article) experienced varying degrees of anxiousness in terms of our Beingin-the-world. Heidegger (1962:232) describes this anxiety as something that "throws Dasein back upon that which [we are] ... anxious about - its authentic potentiality-for-Being-in-the-world". This is a healthy type of anxiety, an anxiety that is characteristic of (and important for) existential beings - we must confront our existence and the fact that it will one day end. However, before we follow Heidegger's thoughts further on this point, a few remarks should be made concerning the predicament of COVID-19, the consequent period of lockdown, and our experiences thereof. 
Perhaps the most pertinent aspect of lockdown was that it restricted our ability to perform our daily tasks, or to follow our daily routines. This is detrimental in the sense that our daily tasks and routines, our work, gave us something meaningful to be engaged with. Even if we had previously experienced these tasks as meaningless, or only superficially meaningful, we still had the opportunity to perform them. Take, for example, the task of Sisyphus in Albert Camus' The myth of Sisyphus (2005). Sisyphus condemned for all eternity to push a rock up a hill only to see it roll back down to the bottom immediately - knows that he has an absurd task. However, Sisyphus still has the opportunity to push the rock up every day - thereby avoiding "the question of whether pushing this rock is his only possibility" (Verhoef 2014:2) - and seeing the rock roll down again and experiencing a moment of happiness with the accomplishment of his task. Although these tasks may seem meaningless, Sisyphus still has a task, a role to fulfil. We may, however, propose for consideration that his movement is not restricted under lockdown regulations - he is free to engage in absurd tasks. Furthermore, he has the potential to ascribe meaning to his task and life,

by accepting the absurd, by recognising and embracing his fate. If, for example, Sisyphus thinks that there is no purpose of existence except to live, then he can fulfil that purpose by just living (Verhoef 2014:3).

Such possibility is taken away - or at least severely restricted - for people who live under extreme lockdown regulations. Imagine Sisyphus sitting at the bottom of the hill, with his rock, condemned not to roll it up. He is a man without a task to execute. In such a situation, only "being" remains, the continuous confrontation of our existence; many people were confronted (inexorably, inescapably) with their own being during COVID-19's lockdown period. The myth of Sisyphus represents, of course,

something of the secularisation of the modern Western world (with its rejection of transcendence) and of the link between (post)modernism and life's absurdity (Verhoef 2014:1)

But there is another (contrasting) way to view our existence and our daily work. This is described by the "Protestant work ethic" - a phrase coined by Max Weber in his seminal book The Protestant ethic and the spirit of capitalism (1905). According to Weber, the Protestant work ethic - also called the Calvinistic or Puritan work ethic - emphasised that every person (not only priests or monks) has a vocation or "calling from God" to perform his/her daily tasks. Such an understanding, hard work, and frugality became part of the Protestant way of life. Protestants should, on this account, be dedicated to their noble vocation, because it is a means to honour God: soli Deo gloria. Such a work ethic brings meaning to people's daily tasks and 
routines (compare with Sisyphus' meaningless activities), but under lockdown conditions, many people found that they could not work and fulfil their godly calling as was ordained by their beliefs. This inactivity may have been a very frustrating experience for people who share this Protestant work ethic or similar understandings of this ideal in other religions (as is encompassed by the Islamic saying that "He who neither worketh for himself, nor for others, will not receive the reward of God" (Al-Suhrawardy 1905)). This disconnect from productive work would definitely increase our sense of meaninglessness, uselessness, and purposelessness - now also in the eyes of God. Not being able to roll the rock up the hill, especially if we contend that this is a divine command or calling, situates us next to Sisyphus at the bottom of the hill contemplating our existence and being, because this is all we can do, without being able to do it.

A final remark, before we focus more on Heidegger. The strict lockdown led to a sense of time "just continuing" as an undifferentiated perpetuation of one moment to the next, from one day to another. This outlandish (and perhaps unnatural) experience of time - with no set events such as work during the week, sport on Saturday, church on Sunday, and so on - created a feeling that "every day is the same". This may be described, in Nietzschean terms, as an extreme awareness of the "eternal recurrence". Everything is recurring, and it will continue to recur again and again, ad infinitum. Following many ancient traditions, Nietzsche argued that this recurrence is eternal. This means that it is not only within our lives that we experience a repetition of the same, but that our whole life might recur again:

Fellow man! Your whole life, like a sandglass, will always be reversed and will ever run out again, - a long minute of time will elapse until all those conditions out of which you were evolved return in the wheel of the cosmic process (Nietzsche 2007:§341).

This thought, argues Nietzsche, is terrifying. He states that it will only be a demon ${ }^{1}$ who curses us into such an existence of repeating the same events (and the same life) over and over again. For Nietzsche, this is a burden of the "heaviest weight" imaginable (Kundera 1999:5) - something that leaves us horrified and paralysed. This experience - we posit - is something that we may experience very concretely during lockdown, especially as our days

1 "What, if some day or night a demon were to steal after you into your loneliest loneliness and say to you: 'This life as you now live it and have lived it, you will have to live once more and innumerable times more; and there will be nothing new in it, but every pain and every joy and every thought and sigh and everything unutterably small or great in your life will have to return to you, all in the same succession and sequence' ... would you not throw yourself down and gnash your teeth and curse the demon who spoke thus?" (Nietzsche 1882:§341). 
appear to become an "eternal recurrence". Surely, such an experience forces us again to face our existence full-on and to contemplate the possibilities for the affirmation of life. ${ }^{2}$

\section{BEING LOST; BEING FOUND}

With this background in mind, we now turn to Heidegger's Being and time (1926). Heidegger welcomes contemplation as regards our existence and being. He may, therefore, argue that the COVID-19 pandemic, with its extreme lockdown regulations, could be a positive experience in the sense that it would force us to consider our existence again. The problem with our "normal" way of living, according to Heidegger, is that we do not think about that we are not confronted with - our being. Our being that is revealed in the everydayness of our existence is one of "fallenness", suggestive of the idea that our being becomes lost. In the context of the COVID-19 pandemic, as different from our average everydayness, we are confronted with our being in such a way that it may be re-investigated with the potential of a more authentic existence. Fallenness does not "express any negative evaluation", but it is used to signify Dasein's absorption into the world; an "absorption in Beingwith-one-another, in so far as the latter is guided by idle talk, curiosity, and ambiguity" (Heidegger 1962:220).

First, the opportunities for idle talk were limited during the lockdown, because we could not socialise as usual. We were isolated from

gossiping and passing the word along - a process by which its initial lack of grounds stand on becomes aggravated to complete groundlessness (Heidegger 1962:212).

The problem with idle talk is that it never uncovers something - it leaves things undone. It discourages "any new inquiry and any disputation, and in a peculiar way suppresses them and holds them back" (Heidegger 1962:213). This might sound trivial, but, in terms of Dasein (our being whose being became an issue for itself), it creates an ever-increasing groundlessness whereby Dasein merely floats along, never considering its existential constitution. When Dasein

2 In The myth of Sisyphus, Camus (2005:1) asserted that there is only one truly serious philosophical problem, and that is suicide - "judging whether life is or is not worth living". This is also our question, especially if we assume that we face the same predicament as Sisyphus, the same fate of "bare repetition" (Taylor 1987:675). 
maintains itself in idle talk, it is - as Being-in-the-world - cut off from its primary and primordially genuine relationships-of-Being towards the world (Heidegger 1962:214).

When we are absorbed in the "they" of idle talk, we thereby miss the opportunity to think about our existence in the world, and just "float" along with everyone else. For a moment, during lockdown, idle talk came to an end. It was a moment of silence and (possible) contemplation. Idle talk did, however, soon resurface in our use of technology, as will be discussed later in this article.

Secondly, curiosity was affected. For Heidegger, curiosity (Neugier) is not only to be inquisitive about something, but it concerns our endless striving for something new, for novelty. Our Being, concealed in everydayness, seeks "novelty only in order to leap from it anew to another novelty": it is a curiosity that "seeks restlessness and the excitement of continual novelty and changing encounters ... concerned with the constant possibility of distraction" (Heidegger 1962:216; his emphasis). This curiosity leads to the constant uprooting of Dasein. In other words, there is no point or time where we sit and rest; a time during which we can contemplate our being. It is rather the case that we pursue - through curiosity - a life that is supposedly genuinely "lively" (Heidegger 1962:217). However, the truth is that such curiosity - together with idle talk - serves only to conceal our Being or Dasein. Hereby, our Being is, in effect, lost and dissipates into thin air.

During the lockdown, it is especially curiosity (in the Heideggerian sense) that is restricted. Excitement about new things to do, to buy, to eat, places to visit, and so on. Everything came to an abrupt end. Suddenly, there was no distraction. Not even sport events (with the Olympic Games, for example, being postponed to a year later) could provide any distraction. We had to accept that there is not really a "lively life" to be found in any events or novelties or distractions, and instead we had to face our own existence, our Dasein. It dawned upon us that perhaps something truly lively is to be found in our being itself, and not in "lively distractions", in curiosity. Technology, albeit problematic in itself, brought some distraction and curiosity back to our lives and seemed to offer reprieve from our confrontation with our being.

Thirdly, ambiguity as constitutive of fallenness was also changed. Ambiguity (Zweideutigkeit) is what is experienced in the combination of idle talk and curiosity and refers to the impossibility to decide "what is disclosed in a genuine understanding, and what is not" (Heidegger 1962:217). The problem is that, through idle talk and curiosity, everything "looks as if it were genuinely understood ... though at the bottom it is not" (Heidegger 1962:217). The difficulty is that we are always, according to Heidegger (1962:219), 
Being with one another, "as thrown Being-with-one-another in a world", so that we cannot escape "them", the "they" who cause this ambiguity. In the end, we understand our Being or Dasein in the "they" and, in this sense, we are "constantly going wrong" (Heidegger 1962:219), because a fallenness in the "they" leads to a disregard of the genuine possibilities of Being. It is on this point, we suggest, that Heidegger would note some potential in the state of lockdown. It is a time of isolation, away from the idle talk, curiosity and ambiguity embedded in the "they". It is an opportunity to discover what Being really implies, because the COVID-19 pandemic breaks the fallenness of our everydayness, of our habitual (but concealed) way of Being. Now - with, ironically, the COVID-19 lockdown - we are (finally) forced into a state of mind where our Being becomes an issue for ourselves.

The dilemma is that modern technology, while functioning as a form of saviour from the perils of isolation and reflection upon ourselves, created the opportunity to embrace once more our fallenness, by providing new means to sustain idle talk, curiosity, and ambiguity. Furthermore, modern technology actually flattened the way we appear to others, conceptualise ourselves, and give meaning to our being. Although modern technology has led to increased connectivity and effectivity of communication during this time, which may be evaluated fairly positively, it has also reduced us to disembodied beings, reduced us to a two-dimensional, flattened screen.

Modern technology has formed an important part of our existence since the 1900s and communication technologies have, for decades, shaped our modern society (Kroes \& Meijers 2016:12; Mitcham 1985:73). However, as a result of the COVID-19 pandemic and lockdown, the technological backbone of our society has been shifted front and centre. We can no longer take walks in the park with friends; these excursions are replaced with coffee dates over video chats. We can no longer attend meetings in person; suddenly, video conferencing has become the norm in the workplace. Our technology would help us in our daily lives, rang the utopian call of the technophile, but it would also save us in a time of crisis. Of course, these technological systems were in place before the lockdown, because our technology had long been considered a modernist form of salvation - at least since the industrial revolution - that echoed the medieval idea of religious deliverance (Noble 2013). ${ }^{3}$

Now, the COVID-19 pandemic and lockdown present the greatest challenge to the functioning of contemporary society and to the livelihood of

3 In this instance, modernist refers specifically to the trends inherent in the modern world view, arising due to the enormous transformations in Western society during the late 19th and early 20th centuries after the movement from the medieval world view through the Renaissance, Reformation, Enlightenment, and the Scientific Revolution (Tarnas 2010). 
millions of individuals that this generation has experienced thus far. In many ways, the pandemic has been a "test-run" or "trial" of our societal systems and, in particular, of our technologies - for ways of being with our technologies that render us always connected, ways of being that see our worlds of engagement become all-digital, and ways of being wherein all aspects of our lives move into virtual spaces. We are forced to engage with digital technology to such an extent that our being is challenged. We became dependent on such forms of technology, but we also experience in its sporadic breakdowns much frustration that reflects our increasing reliance thereupon.

\section{THE HAMMER: TECHNOLOGICAL RELIANCE AND BREAKDOWN}

Heidegger describes Dasein's existential relation to the world through the image of a broken hammer. A key image for Heidegger's early conceptualisation of technology in Being and time (1962) is the hammer as equipment (das Zeug). Equipment is an object in the world with which we have meaningful dealings and the use of which is an "in-order-to" for Dasein. ${ }^{4}$ The hammer, as the example, forms part of some broader sociotechnical system that presents specific material conditions of possibility. For Heidegger, the hammer has a "towards-which" or a directedness towards work (i.e. towards that which is produced by the use of the hammer), and, in this sense, objects are comported to Being at the same time that our Being is comported through its use. ${ }^{5}$ When the hammer breaks, however, there is a resultant onto-epistemological rupture, because unusable equipment leads to an awareness of the object of use as an object in itself: a broken hammer forces itself upon us to lead us to further

4 Another description of equipment is the word "tool", the tool being a thing with which we can work within a realm of possibilities of usefulness in that thing's particular context. Equipment should be thought of as a collective noun, however, and thus the term "tool" is not regularly utilised in describing Heidegger's early ideas on technology. Thus, there exist for the hammer useful possibilities (such as hammering in a nail), but only within a particular equipment totality to which the hammer belongs (for a hammer without a nail is useless) (Heidegger 1962).

5 Heidegger refers to equipment in relation to work as follows: "The work to be produced, as the 'towards-which' of such things as the hammer, the plane, and the needle, likewise has the kind of Being that belongs to equipment" (Heidegger 1962:99). The first mode of equipment comportment to being is the equipment as ready-to-hand (zuhanden), as a means whereby we work and act. In this use, the equipment becomes transparent to us through its effective and proper usage. The object exists in its role only in our action. The second mode of equipment comportment to Being is when a ready-to-hand object breaks, and we are forced to recognise it as present-at-hand (vorhanden). The present-at-hand mode, which is the usual notion of objects as substantial entities observed or thought of as independent and over and against us, is reflected in the broken hammer. Traditional philosophy treated all objects as present-at-hand. 
theoretical reflection on our everyday unencumbered use of the object. ${ }^{6}$ There is a shock, a realisation. The hammer becomes conspicuous, and unready-tohand (we cannot make use of it) - it reveals both the intentionality of the user and the equipment context wherein the hammer functions.

Generally, we do not recognise how reliant we have become on technology for many everyday tasks, specifically during the lockdown, until our technologies break down. We fail to recognise that we are alone in a room until, during a video meeting, the connection drops and we are forced to reconsider the technology that has allowed us to communicate. When the technology is functioning correctly, we find that speaking with others across vast distances is an ability we do not need to think about, because the technological artefacts are ready-to-hand and form part and parcel of our potentialities - technology may be presumed to be entirely positive in granting us this ability. The entirety of our Being is swept along with the skilful use of our technologies, and we are unaware of how technology speaks to our everydayness. We can function with some semblance of normality, engage with others almost in the same way as we have done in pre-lockdown times, but only until the technological artefact becomes present-at-hand - when it breaks, or the connection is lost. Such instances lead us to reconsider the situation we are in, and to realise how precarious our contact with others truly is, while at the same time bring the question of our Being to the surface. When technology breaks down, it directs us back to the core of our Being, to our Dasein, and a concurrent sense of isolation. Thus, while technology has assisted in addressing many problems related to the current pandemic, it is at the point of technological breakdown (and even merely after a couple of months of constant technology use) that we find the use of such digital ways of communication and living are unsatisfying and cannot replace face-to-face contact with others. When technology breaks down, the veil drops and our Being asserts itself, rising up against the structured and artificial character of our technologies. The digital is too reduced, too limited, too unlike our nontechnological existence. We recognise a need for close encountering of the other, for a physical closeness, a need that Heidegger's account of technology suggests as crucial for understanding fallenness. ${ }^{7}$

6 The broken hammer shows us the material conditions of possibility produced thereby.

7 In the early and the later Heidegger, there reside two distinct and varied accounts of technology. It is necessary to distinguish these two accounts to make sense of the varieties of technological analyses that Heidegger brings to the table in our rethinking of our use of technology during the time of the Covid-19 pandemic and lockdown. The early Heideggerian discussion of technology is typified in Being and time (1926) through Heidegger's discussion of the tool-like character of being itself. The tool-like mode of existence was central to Heidegger's earlier philosophy. Importantly, the discussion of technology is an explication of not only technology itself, but also of the equipment functioning of Dasein (from there the rather brief treatment of the subject in 


\section{ENFRAMING TECHNOLOGIES}

During the lockdown, we found that technology functioned to reinforce our fallenness, rather than allowing us to overcome the said fallenness, through the flattening of our encounter with the world and with others - the world and others literally become flat images on a screen, while simultaneously being reduced in dimensionality and complexity. In The question concerning technology (1977), Heidegger describes how modern technology defines the present era of humanity and "enframes" everything with its orientation - technology structures - and makes our dealings with the world shallow. ${ }^{8}$ Things in the world and all of nature (including others) become resources to be used, a "standing reserve". ${ }^{9}$ During the lockdown, we begin to think along these same lines: others become disposable, easily ordered and arranged. Friends, family members, and colleagues become moving pictures or avatars on a screen. Mere images, of course, have hardly any value and may just as easily be replaced by some other form of screen-based entertainment or some other person. Our experience of the world has become flattened through our forced engagement with others via technology - others have, in effect, become enframed through the functioning of modern technology..$^{10}$ In fact, all of the reality with which we engage has been, through enframing by modern communication technology, set "upon man [sic.] to order the real as standing-reserve" (Heidegger 1977:19). ${ }^{11}$

Being and time) - only in Heidegger's later works, such as The question concerning technology (1977), does the topic of technology become a subject of direct philosophical reflection itself.

8 Ge-stell is the German word for "enframing". While insightful, Heidegger's thought on technology becomes much more focused on the topic of technology itself in his later work. There are some argumentative aspects of Being and time that are relevant for his later thought on technology, such as the idea that theoretical activity (such as the natural sciences) implicitly narrows and restricts our understanding of the everyday world of concern and action. Neutral mathematical understanding cannot allow us to meaningfully construct distance and direction in space, for example, or understand the opportunities provided by action - such detached thinking flattens out the richness of our ordinary concern. Concernful dealings within the world allow a more truthful and fundamental understanding of being human, but science negates such concern.

9 Clearly, our current misuse of the environment tells the tale of how technological thinking leads to destruction - the cost-benefit analysis is de rigueur across all spheres of society. Zimmerman (1977:79) states that "[t]o be capable of transforming a forest into packaging for cheeseburgers, man [sic.] must see the forest not as a display of the miracle of life, but as raw material, pure and simple".

10 They have also become, in a sense, literally enframed - i.e. they have been placed in a frame.

11 According to Heidegger (1977:26), "placed between these possibilities, man [sic.] is endangered from out of destining". In this sense, enframing is for Heidegger the default of two different "ordainings of destining" for human beings caused by technology (Heidegger 1977: 25). 
Enframing also delimits our ability to engage with non-technological ways of understanding the world (such as the wisdom of pre-industrial peoples which becomes inaccessible to us), while also obfuscating the all-encompassing functioning of technological enframing per se. This effect is heightened during the lockdown, because it is necessary to engage with all aspects of our lives through technology on a continuous basis. Our immersion in technology makes us unaware of alternative ways of being in the world, because the technological attitude has become synonymous with sound or correct thinking and no alternatives are suggested. We become convinced that "this is the way things should be". During lockdown, we recognise that, unlike face-toface conversations, our use of technology renders us unfree to act in certain ways (such as touching another person). We forcefully had to adapt to being unfree - this is the extent of what our circumstances and technologies allow us - which is an approach to existence that is contrary to Heidegger's call for deeper inquiry into Dasein.

\section{THE SHEPHERDS OF BEING}

Along these lines, Heidegger suggests that, while we are not in control of technology, we may indeed be able to stand in a free relation to technology through an understanding of what the essence of technology entails. Never has the recognition of Dasein been more important than during the lockdown, because, during this time, we have little vision of our everyday lives beyond what is provided by technology. A free relation to technology, therefore, entails that, through careful consideration of our technological use, we may utilise technology without being subsumed into its enframing and calculative processes. Heidegger suggests that we are "Shepherds of Being" and that we have been granted the power to reveal the world in certain ways (Ballard 1971:60). This recognition of Dasein leads to a freer relation with technology during the lockdown. In the process of comprehending the essence and thinking behind technology, we become free to choose our relationship with our technological objects, allowing us to "[sojourn] in the open space of destining" (Heidegger 1977:26). In fact, through examples such as the modern highway interchange (Dreyus \& Spinosa 1997), Heidegger suggests that technological artefacts may lead us to a closer grasp of Being - technology may become a means to focus on crucial aspects of our Being. What does the use of communication technologies during lockdown tell us about our existence?

Following on from the idea that we are Shepherds of Being, and that the deeper engagement with Dasein is crucial herein, we realise that technology is so unsatisfying during the lockdown, because its use leads, perilously, to a disregard or negation of our Dasein. Dasein is not simply to be understood as an abstract or rationalist concept; rather, it is part of our life world and 
is embodied in our everydayness (Du Toit \& Verhoef 2018:5). Dasein is understood in movement and touch, and in relation with others, face-toface. When we engage with technology, we lose such crucial aspects of the fullness of our existence that undoubtedly result in a flattening of our being. We have a need for closeness, because our Dasein is embodied, and as long as our technologies do not support such "shepherding" processes (through a recognition and consideration of embodied being), we will always find that the technological presents a restriction to our Dasein, an enframement, a delimitation, and an incompleteness.

\section{CONCLUSION}

So, what can we learn about Being-in-the-COVID-19-world?

One, technology encompasses our being and reveals that, in trying to escape from our being through digital technology, we might actually be escaping from the fullness of being itself - clearly an impossibility but constraining of our existence, nonetheless. Our technology use can lead us to idle talk, to curiosity, to ambiguity, and thus to a further fallenness (because all ways of encountering the world are pre-programmed and structured via such technology). Tracing technology through the lens of Dasein reveals two possible reasons why our experience of technology during lockdown, rather than being liberating, is so unsatisfying: first, technology reinforces our fallenness through its enframing function and, secondly, it is unable to account for Dasein as embodied within our everydayness. We must encounter others in the non-technological space as embodied others, as beings that exist beyond ourselves and beyond the confines of the screen, because technology alone leads us to ever more reduced ways of being that could only ever lead to fallenness. The recognition of, and deeper inquiry into Dasein is crucial for rethinking our use of technology.

Two, the positive outcome of COVID-19 and the lockdown can thus be described in Heideggerian terms as the opportunity to think about our existence more authentically, away from the fallenness of the ontological structure of Dasein in its everydayness. It offers us the opportunity to consider at least our authenticity, our possible authentic existence that is

not something which floats above falling everydayness; existentially, it is only a modified way in which such everydayness is seized upon (Heidegger 1962:224).

Authentic existence concerns our "ownmost and uttermost potentiality-forBeing" (Heidegger 1962:307), a freedom for living-towards-death, where we come face to face with the possibility of being itself, as a freedom that "has 
been released from the illusions of the 'they' and which is factical, certain of itself, and anxious" (Heidegger 1962:311). To experience anxiousness during COVID-19 is thus something positive. To be restricted in our movement, in our curiosity and fulfilling of our daily tasks - our everyday existence - is also something positive. It has the potential to help us realise the authentic possibilities of our own being - a freedom we have in our Being-towards-death.

\section{BIBLIOGRPAHY}

AL-SUHRAWARDY, A.A.M. 1905. Sayings of Muhammad. Secaucus: Citadel Press.

BALLARD, E.G. 1971. Philosophy at the crossroads. Baton Rouge, LA: LSU Press.

Camus, A.

2005. The myth of Sisyphus. Translated by J. O'Brien. London: Penguin.

DREYUS, H.L. \& SPINOSA, C.

1997. Highway bridges and feasts: Heidegger and Borgmann on how to affirm technology. Man and World 30(2):159-178. https://doi.org/10.1023/A:1004299524653

Du Preez, P. \& Le Grange, L.

2020. The COVID-19 pandemic, online teaching/learning, the digital divide and epistemological access. In: L. Ramrathan, J. Smit, N. Hlongwe \& N. Mkhize (eds.), Humanities curriculum within the context of COVID-19 (Durban: Alternation), in print.

DU TOIT, J. \& VERHOEF, A.H.

2018. Embodied digital technology and transformation in higher education. Transformation in Higher Education 3(0):a52, 1-8. https://doi.org/10.4102/the.v3i0.52

GREENBERG, G.

2020. Therapy under lockdown: "I'm just as terrified as my patients are". The Guardian, UK, 23 April.

HEIDEgGeR, M.

1962 [1926]. Being and time. Translated by J. Macquarrie \& E. Robinson. Oxford: Blackwell.

1977. The question concerning technology. New York: Harper \& Row.

KRoes, P. \& MeIJeRS, A.W.

2016. Toward an axiological turn in the philosophy of technology. In: M. Franssen, P.E. Vermaas, P. Kroes \& A.W. Meijers (eds.), Philosophy of technology after the empirical turn (Heidelberg: Springer Verlag), pp. 11-30. https://doi. org/10.1007/978-3-319-33717-3_2 
KUNDERA, M.

1999. The unbearable lightness of being. New York: Harper Perennial.

MITCHAM, C.

1985. What is the philosophy of technology? International Philosophical Quarterly 25(1):73-88. https://doi.org/10.5840/ipq198525149

NiETZSCHE, F.

1882. The gay science. New York: Vintage.

2007. The complete works of Friedrich Nietzsche, Volume 16 (Twilight of the idols; the antichrist; Eternal recurrence; Notes to Zarathustra). Edited by O. Levy. Translated by A.M. Ludovici. New York: Macmillan.

NoBLE, D.F.

2013. The religion of technology: The divinity of man and the spirit of invention. New York: Knopf.

TARNAS, R.

2010. The passion of the Western mind: Understanding the ideas that have shaped our world view. New York: Random House.

TAYLOR, R.

1987. Time and life's meaning. Review of Metaphysics 40(4):675-686.

VERHOEF, A.H.

2014. Sisyphus, happiness and transcendence. South African Journal of Philosophy 33(4):537-546. https://doi.org/10.1080/02580136.2014.976757

WEBER, M.

1905. The Protestant ethic and the spirit of capitalism. Translated by T. Parsons. New York: Dover.

World Health Organization WHO)

2020. Mental health \& COVID-19. [Online.] Retrieved from: https://www.who.int/ teams/mental-health-and-substance-use/covid-19 [23 June 2020].

ZIMMERMAN, M.

1977. Beyond humanism: Heidegger's understanding of technology. Listening 12(3):74-83.

$\begin{array}{ll}\text { Keywords } & \text { Trefwoorde } \\ \text { COVID-19 } & \text { COVID-19 } \\ \text { Embodiment } & \text { Beliggaming } \\ \text { Heidegger } & \text { Heidegger } \\ \text { Technology } & \text { Tegnologie }\end{array}$

